Review

\title{
Neospora caninum Infection in Cattle and Dogs in Iran: A Systematic Review and Meta-Analysis
}

\author{
${ }^{1}$ Mohammad Jokar, ${ }^{2}$ Saied Bokaie, ${ }^{3 *}$ Vahid Rahmanian, \\ ${ }^{3}$ Razieh Zahedi, ${ }^{3}$ Nader Sharifi and ${ }^{4}$ Hekmatollah Khoubfekr \\ ${ }^{I}$ Faculty of Veterinary Medicine, Karaj Branch, Islamic Azad University, Karaj, Iran \\ ${ }^{2}$ Department of Food Hygiene and Quality Control, Division of Epidemiology and Zoonoses, \\ Faculty of Veterinary Medicine, University of Tehran, Tehran, Iran \\ ${ }^{3}$ Zoonoses Research Center, Jahrom University of Medical Sciences, Jahrom, Iran \\ ${ }^{4}$ Iranshahr Health Services, Iranshahr University of Medical Sciences, Iranshahr, Iran
}

Article history

Received: 01-11-2020

Revised: 26-12-2020

Accepted: 23-01-2021

Corresponding Author:

Vahid Rahmanian

Zoonoses Research Center,

Jahrom University of Medical

Sciences, Jahrom, Iran

Email: vahid.rahmani1392@gmail.com

\begin{abstract}
Neosporosis, a parasitic infection caused by Neospora caninum (N. caninum), is one of the main contagious factors that cause reproductive disturbances in cattle and neuromuscular complaints in dogs. This review was performed to determine the prevalence of cattle and dogs neosporosis in Iran. Data were systematically gathered from January 2004 to July 2020 in the Islamic Republic of Iran from the following electronic databases: PubMed, Google Scholar, Science Direct, Scopus, Web of Science, Elmnet, Magiran, Irandoc, Iranmedex, Scientific Information Database (SID) and civilica. In cattle, 57 studies and in dogs 28 studies reporting the prevalence of neosporosis in different areas of Iran found which met our eligibility criteria. In total, the pooled prevalence of neosporosis, using a randomeffect model, was estimated $24.2 \%$ (95\% CI, 21.5-26.9) in cattle and $19.9 \%$ (95\% CI, 15.3-24.4) in dogs. Furthermore, the majority of neosporosis cases were in the Southwest (37\% in cattle and $30.6 \%$ in dogs) provinces of Iran. In conclusion, the pooled prevalence of cattle and dogs neosporosis in Iran is relatively high. This value differs among geographical regions as it is the maximum in the southwest for both and the minimum in the northeast for cattle and the southeast for dogs of Iran. These results are desirable for managing the control programs of this infection.
\end{abstract}

Keywords: Neospora, Bovine, Canine, Epidemiology, Prevalence, Iran

\section{Introduction}

Neospora caninum is an obligate intracellular apicomplexan protozoan parasite and recognized as the main cause of abortion in cattle and of neuromuscular complaints in dogs (Jin et al., 2017; Silva and Machado, 2016; Reichel et al., 2020). Domestic dogs, Australian dingoes, coyotes and gray wolf are can serve as both definitive and intermediate hosts of the $N$. caninum (Dwinata et al., 2018; Curtis et al., 2020), which shed many numbers of oocyst in their feces and contaminating the setting (Khan et al., 2020; Rocchigiani et al., 2017; Klein et al., 2019). Dogs and Intermediate hosts including cattle, horses, birds, goats, sheep, deers and buffaloes develop infected with the parasite by ingesting contaminated water or diet and by trans-placental infection. However, the protozoan can be transmitted to dogs of spring over several generations (Klein et al.,
2019; González-Warleta et al., 2018; Fereig and Nishikawa, 2020). Vertical transmission is considered as the main road of spread and is critical for the maintenance of $N$. caninum in a bovine herd (González-Warleta et al., 2018; de Aquino Diniz et al., 2019).

In dogs, $N$. caninum caused different clinical signs according to age, breed and infected tissues; such as muscle atrophy, polymyositis, myocarditis, dermatitis, severe hepatitis, peritonitis, pneumonitis, stillbirths, neonatal deaths and neurological symptoms (Didiano et al., 2020; Decôme et al., 2019; Coelho et al., 2019; Moore and Venturini, 2018). However, N. caninum is deliberated as one of the important reasons for abortion in cattle; It follows sporadic, endemic and epidemic abortion patterns, being responsible for the economic burden in the cattle industry globally (Liu et al., 2020; de Oliveira et al., 2019). Other consequences are fetal death, resorption, mummification, 
autolysis, stillbirth, or birth of clinically affected or normal calves but persistently infected (Dubey et al., 2017; Marugan-Hernandez, 2017).

The economic impacts of neosporosis in cattle herds are direct (abortion) and indirect (including earlier culling of seropositive cattle, costs of veterinary medical treatment and diagnosis of illness, decreased milk production, reduction in growth rates, etc.) (Liu et al., 2020; Demir et al., 2020). Although there are some reports on $N$. caninum infection's effects on milk production, many studies indicated that it may decrease in seropositive cows. Through, others reported milk production growths in seropositive cattle (Reichel et al., 2020; Chatziprodromidou and Apostolou, 2018).

In the context of this study focused on Iran, several studies reported that the prevalence of $N$. caninum in cattle and dogs. It is important to understand the epidemiology of cattle and dog neosporosis in all regions in Iran, to implement control and prevention programs that decrease the economic burden caused by the infection. This study is aimed to determine the overall prevalence of cattle and dog neosporosis in the Islamic Republic of Iran by systematic review and meta-analysis.

\section{Materials and Methods}

This study was designed as suggested via the Preferred Reporting Items for Systematic Reviews and Meta-Analyses (Liberati et al., 2009).

\section{Bibliographic Search Strategy}

All studies with epidemiological parameters are including the prevalence of $N$. caninum infection among cattle and dogs were the concern of this study. The relevant studies have been identified from January 2004 to July 2020 from five English sources i.e., Pub Med, Google Scholar, Science Direct, Scopus, Web of Science and five Persian databases namely, Elmnet, Civilica, Magiran, Irandoc and Scientific Information Database (SID). Dissertations (Theses) $(n=13)$ and Congress paper $(n=6)$ were collected from Irandoc and Civilica respectively. The selection process of studies is in view in the PRISMA Flowchart as shown in Fig. 1.

The search was implemented using the keywords as follows: Bovine, Canine, Cattle, Cow, Dog, Meat producing animal, Neospora caninum, Neospora, Neosporosis, Neosporosis in Animal, anti-Neospora antibodies, Epidemiology, Prevalence, Seroprevalence and Iran either alone or in combination and both Persian (Farsi) and English.

\section{Data Collection}

The titles and abstracts found in the search were independently reviewed by two of us as the authors, for checking inclusion and exclusion criteria. Differences of opinion between the specialists were resolved by a third person independently and consensus. All studies carried out to estimate the prevalence of neosporosis, detected by using different diagnostic approaches on cattle and dog were included. If studies were duplicates and not report $N$. caninum prevalence in cattle or dog were excluded.

The collected data for the present study were as follows: Time of publication, the first author, the geographical focus of the study, sample size, diagnostic tests, type of array in a diagnostic test and prevalence rate were extracted from the eligible studies. For this objective, an Excel data extraction form was used (Table 1).

Table 1: Papers met the eligibility criteria of this systematic review and meta-analysis

\begin{tabular}{|c|c|c|c|c|c|c|c|c|}
\hline Authors & $\begin{array}{l}\text { Year of } \\
\text { publication }\end{array}$ & District & Province & $\begin{array}{l}\text { Diagnostic } \\
\text { test }\end{array}$ & $\begin{array}{l}\text { Cut off } \\
\text { point }\end{array}$ & $\begin{array}{l}\text { Sample } \\
\text { size }\end{array}$ & $\begin{array}{l}\text { Total number } \\
\text { of positive }\end{array}$ & $\begin{array}{l}\text { Overall } \\
\text { prevalence }(\%)\end{array}$ \\
\hline Hosseininejad et al. & 2017 & Center & Isfahan & ELISA & SIn $>0.153$ & 1500 & 395 & 26.33 \\
\hline Nourollahi-Fard et al. & 2017 & Northeast & Razavi Khorasan & ELISA & $\mathrm{PP} \geq 20$ & 100 & 26 & 26.00 \\
\hline Gharekhani et al. & $2014 a$ & West & Hamedan & ELISA & $\mathrm{S} / \mathrm{P} \geq 0.5$ & 492 & 63 & 12.80 \\
\hline Heidari et al. & 2014 & West & Kurdistan & ELISA & $\mathrm{S} / \mathrm{P} \geq 0.5$ & 368 & 29 & 7.80 \\
\hline Hadad Zadeh et al. & 2010 & North & Tehran & ELISA & $\mathrm{S} / \mathrm{P} \geq 0.5$ & 768 & 298 & 38.80 \\
\hline Fard et al. & 2008 & Southeast & Kerman & ELISA & $\mathrm{PP} \geq 20$ & 285 & 36 & 12.60 \\
\hline Yousefi et al. & 2009 & North & Mazandaran & ELISA & $\mathrm{S} / \mathrm{P} \geq 0.5$ & 237 & 76 & 32.00 \\
\hline Yagoob & $2012 \mathrm{a}$ & Northwest & East Azerbaijan & ELISA & $P P \geq 20$ & 236 & 42 & 17.70 \\
\hline Gharekhani and Heidari & 2014 & West & Hamedan & ELISA & $\mathrm{S} / \mathrm{P} \geq 0.40$ & 1406 & 245 & 17.40 \\
\hline Sattari et al. & 2011 & Northeast & Golestan & ELISA & $\mathrm{S} / \mathrm{P} \geq 0.5$ & 800 & 107 & 13.37 \\
\hline Nematollahi et al. & $2011 \mathrm{a}$ & Northwest & East Azerbaijan & ELISA & SIn $>0.153$ & 266 & 28 & 10.50 \\
\hline Hamidinejat et al. & 2013 & South & Fars & ELISA & $\mathrm{S} / \mathrm{P} \geq 0.5$ & 178 & 95 & 53.30 \\
\hline Haji Hajikolaei et al. & 2008 & Southwest & Khuzestan & ELISA & $\mathrm{S} / \mathrm{P} \geq 0.5$ & 557 & 117 & 21.00 \\
\hline Gharekhani and Tavoosidana & 2013 & West & Hamedan & ELISA & $\mathrm{S} / \mathrm{P} \geq 0.5$ & 514 & 102 & 19.80 \\
\hline Razmi et al. & 2006 & Northeast & Razavi Khorasan & ELISA & $\mathrm{AV}>0.2$ & 337 & 156 & 46.29 \\
\hline Noori et al. & 2019 & Southeast & Sistan and Baluchestan & ELISA & $\mathrm{S} / \mathrm{P} \geq 0.5$ & 184 & 7 & 3.80 \\
\hline Sadrebazzaz et al. & 2004 & Northeast & Razavi Khorasan & IFA & 1.200 & 810 & 123 & 15.18 \\
\hline Ansari-Lari et al. & 2017 & South & Fars & ELISA & $\mathrm{S} / \mathrm{P} \geq 0.5$ & 253 & 77 & 30.40 \\
\hline Gharekhani and Yakhchali & 2019 & West & Hamedan & ELISA & $\mathrm{S} / \mathrm{P} \geq 0.5$ & 476 & 118 & 24.80 \\
\hline Nematollahi et al. & $2011 b$ & Northwest & East Azerbaijan & ELISA & $\mathrm{S} / \mathrm{P} \geq 0.3$ & 76 & 13 & 18.40 \\
\hline Adhami et al. & 2014 & West & Kurdistan & ELISA & $\mathrm{S} / \mathrm{P} \geq 0.5$ & 336 & 64 & 17.60 \\
\hline Ranjbar et al. & 2010 & North & Semnan & ELISA & $\mathrm{S} / \mathrm{P} \geq 0.5$ & 104 & 40 & 38.50 \\
\hline
\end{tabular}




\begin{tabular}{|c|c|c|c|c|c|c|c|c|}
\hline Gharekhani et al. & 2012 & West & Hamedan & ELISA & $\mathrm{S} / \mathrm{P} \geq 0.5$ & 400 & 80 & 20.00 \\
\hline Sabevarinejad et al. & 2013 & West & Lorestan & ELISA & $\mathrm{S} / \mathrm{P} \geq 0.5$ & 181 & 50 & 27.62 \\
\hline Adhami et al. & 2015 & West & Kurdistan & IFA & 1.200 & 410 & 69 & 16.82 \\
\hline Javanshir & 2015 & Center & Qom & ELISA & $\mathrm{S} / \mathrm{P} \geq 0.5$ & 200 & 18 & 8.00 \\
\hline Atashgahi & 2015 & Northeast & Razavi Khorasan & ELISA & $\mathrm{S} / \mathrm{P} \geq 0.5$ & 250 & 45 & 18.00 \\
\hline Asadi Karam & 2016 & Southeast & Kerman & ELISA & $\mathrm{S} / \mathrm{P} \geq 0.40$ & 93 & 12 & 12.90 \\
\hline Forooghi & 2013 & West & Lorestan & ELISA & $\mathrm{S} / \mathrm{P} \geq 0.5$ & 184 & 52 & 28.26 \\
\hline Motamedi Pour & 2016 & Southeast & Kerman & ELISA & $\mathrm{S} / \mathrm{P} \geq 0.5$ & 150 & 14 & 9.30 \\
\hline Noaman and Nabinejad & 2020 & Center & Isfahan & ELISA & $\mathrm{S} / \mathrm{P} \geq 0.5$ & 216 & 41 & 19.00 \\
\hline Jokar et al. & 2018 & Center & Qom & ELISA & $\mathrm{S} / \mathrm{P} \geq 0.5$ & 83 & 20 & 25.00 \\
\hline Davasaz & 2009 & Northwest & East Azerbaijan & ELISA & $\mathrm{S} / \mathrm{P} \geq 0.5$ & 370 & 68 & 18.50 \\
\hline Tavasolian et al. & 2010 & North & Semnan & ELISA & $\mathrm{S} / \mathrm{P} \geq 0.5$ & 104 & 26 & 25.00 \\
\hline Kamkar-Salehi and Namavari & 2017 & South & Fars & ELISA & $\mathrm{S} / \mathrm{P} \geq 0.5$ & 184 & 34 & 19.00 \\
\hline Shabani et al. & 2017 & Northwest & Qazvin & ELISA & $\mathrm{S} / \mathrm{P} \geq 0.5$ & 160 & 40 & 21.00 \\
\hline Ansarifar & 2011 & North & Tehran & ELISA & $\mathrm{S} / \mathrm{P} \geq 0.5$ & 210 & 35 & 17.00 \\
\hline Youssefi et al. & & Northwest & and Mazandaran & ELISA & $\mathrm{S} / \mathrm{P} \geq 0.5$ & 46 & 3 & 7.00 \\
\hline Razmi et al. & 2014 & Northeast & Razavi Khorasan & ELISA & $\mathrm{S} / \mathrm{P} \geq 0.5$ & 200 & 38 & 19.00 \\
\hline Nayebzadeh et al. & 2015 & West & Lorestan & ELISA & $\mathrm{S} / \mathrm{P} \geq 0.5$ & 347 & 34 & 9.80 \\
\hline \multirow[t]{2}{*}{ Namavari et al. } & 2012 & $\begin{array}{l}\text { South and } \\
\text { Southwest }\end{array}$ & $\begin{array}{l}\text { Fars, Khuzestan } \\
\text { and Kohgiluyeh }\end{array}$ & & & & & \\
\hline & & & and Boyer-Ahmad & ELISA & $\mathrm{S} / \mathrm{P} \geq 0.5$ & 56 & 22 & 39.28 \\
\hline Saber et al. & 2010 & Northwest & East Azerbaijan & ELISA & $\mathrm{S} / \mathrm{P} \geq 0.5$ & 136 & 24 & 17.60 \\
\hline Ahmad et al. & 2011 & Northwest & East Azerbaijan & ELISA & $\mathrm{S} / \mathrm{P} \geq 0.5$ & 32 & 7 & 20.00 \\
\hline Nemat and Jafari & 2010 & Northwest & East Azerbaijan & ELISA & $\mathrm{S} / \mathrm{P} \geq 0.5$ & $\mathrm{IgG}$ & 116 & 23.00 \\
\hline Nematollahi et al. & 2013 & Northwest & East Azerbaijan & ELISA & $\mathrm{S} / \mathrm{P} \geq 0.5$ & $\mathrm{IgG}$ & 76 & 14.00 \\
\hline Pazoki Plasht et al. & 2008 & North & Tehran & ELISA & $\mathrm{S} / \mathrm{P} \geq 0.5$ & 150 & 26 & 17.33 \\
\hline Hamidinejat et al. & 2015 & Southwest & Khuzestan & ELISA & $\mathrm{S} / \mathrm{P} \geq 0.5$ & 108 & 58 & 53.70 \\
\hline Binaee & 2017 & North & Semnan & ELISA & $\mathrm{S} / \mathrm{P} \geq 0.5$ & 237 & 67 & 28.27 \\
\hline Moraveji & 2012 & South & Fars & ELISA & $\mathrm{S} / \mathrm{P} \geq 0.5$ & 164 & 23 & 14.00 \\
\hline Shahidi & 2018 & Northeast & Razavi Khorasan & ELISA & $\mathrm{S} / \mathrm{P} \geq 0.5$ & 280 & 45 & 16.08 \\
\hline Behnaz & 2017 & Southwest & Khuzestan & ELISA & $\mathrm{S} / \mathrm{P} \geq 0.5$ & 280 & 87 & 32.07 \\
\hline Mohammad Ali Gol & 2010 & Southwest & Khuzestan & ELISA & $\mathrm{S} / \mathrm{P} \geq 0.5$ & 178 & 95 & 53.30 \\
\hline Sharifdini et al. & 2011 & Northwest & Ardabil & ELISA & $\operatorname{SIn} \geq 0.23$ & 171 & 52 & 30.40 \\
\hline Gharekhani and Heidari & 2014 & West & Hamedan & ELISA & $\mathrm{S} / \mathrm{P} \geq 0.40$ & 270 & 73 & 27.00 \\
\hline Yagoob & $2012 b$ & Northwest & East Azerbaijan & IFAT & $1: 50$ & 100 & 31 & 31.00 \\
\hline Ghanavati & 2015 & Southwest & Khuzestan & IFAT & $1: 50$ & 150 & 30 & 20.00 \\
\hline Pouramini et al. & 2017 & Center & Tehran & ELISA & $\mathrm{S} / \mathrm{P} \geq 0.5$ & 42 & 1 & 2.22 \\
\hline Khanmohammadi and Fallah & 2011 & Northwest & East Azerbaijan & IFAT & $1: 50$ & 384 & 41 & 10.60 \\
\hline Gharekhani et al. & $2014 b$ & West & Hamedan & IFAT & $1: 50$ & 270 & 70 & 27.00 \\
\hline Haddadzadeh et al. & 2007 & North & Tehran & IFAT & $1: 50$ & 103 & 20 & 19.40 \\
\hline Hosseininejad et al. & $2010 \mathrm{a}$ & $\begin{array}{l}\text { West and } \\
\text { Central }\end{array}$ & $\begin{array}{l}\text { Chahar mahal va } \\
\text { Bakhtiari, Isfahan }\end{array}$ & IFAT & $1: 50$ & 233 & 24 & 10.30 \\
\hline Hosseininejad and Hosseini & 2011 & $\begin{array}{l}\text { West and } \\
\text { Central }\end{array}$ & $\begin{array}{l}\text { Chaharmahal va } \\
\text { Bakhtiari, Isfahan } \\
\text { Khuzestan }\end{array}$ & ELISA & $\mathrm{S} / \mathrm{P} \geq 0.5$ & 548 & 159 & 37.90 \\
\hline Razmi & 2009 & Northeast & Razavi Khorasan & PCR & $\begin{array}{l}\text { Gene- Nc5 } \\
\text { genomic fragment }\end{array}$ & 174 & 4 & 2.20 \\
\hline Hosseininejad and Hosseini & 2019 & Southwest & Khuzestan & ELISA & $\mathrm{S} / \mathrm{P} \geq 0.5$ & 100 & 18 & 18.00 \\
\hline Raeisi & 2009 & West & Chaharmahal va Bakhtiari & IFAT & $1: 50$ & 200 & 55 & 27.50 \\
\hline Hosseininejad et al. & 2017 & Center & Isfahan & ELISA & $\operatorname{SIn}>0.153$ & 113 & 20 & 17.69 \\
\hline Gharekhani et al. & $2014 \mathrm{a}$ & West & Hamedan & ELISA & $\mathrm{S} / \mathrm{P} \geq 0.5$ & 360 & 36 & 10.00 \\
\hline Gharekhani and Heidari & 2014 & West & Hamedan & IFAT & $1: 50$ & 270 & 73 & 27.00 \\
\hline Gharekhani and Tavoosidana & 2013 & West & Hamedan & ELISA & $\mathrm{S} / \mathrm{P} \geq 0.5$ & 454 & 93 & 20.50 \\
\hline Gharekhani and Yakhchali & 2019 & West & West Azerbaijan & ELISA & $\mathrm{S} / \mathrm{P} \geq 0.5$ & 185 & 16 & 8.60 \\
\hline Javanshir & 2015 & Center & Qom & ELISA & $\mathrm{S} / \mathrm{P} \geq 0.5$ & 50 & 2 & 4.00 \\
\hline Gharekhani et al. & 2019 & West & Hamedan & ELISA & $\mathrm{S} / \mathrm{P} \geq 0.5$ & 180 & 9 & 5.00 \\
\hline Yakhchali et al. & 2017 & Northwest & West Azerbaijan & IFAT & $1: 50$ & 137 & 17 & 12.40 \\
\hline Khordadmehr & 2012 & Southwest & Fars & ELISA & $\mathrm{S} / \mathrm{P} \geq 0.5$ & 108 & 59 & 54.62 \\
\hline Hosseininejad et al. & $2010 b$ & West & Chaharmahal va Bakhtiari & IFAT & $1: 50$ & 100 & 32 & 32.00 \\
\hline Yagoob & $2012 b$ & Northwest & East Azerbaijan & IFAT & $1: 50$ & 100 & 31 & 31.00 \\
\hline Ghafarifar et al. & 2014 & West & lorestan & PCR & $\begin{array}{l}\text { Gene- Nc5 } \\
\text { genomic fragment }\end{array}$ & 428 & 9 & 2.10 \\
\hline Keyhani & 2017 & Center & Isfahan & PCR & $\begin{array}{l}\text { Gene- Nc5 } \\
\text { genomic fragment }\end{array}$ & 100 & 22 & 22.00 \\
\hline
\end{tabular}

Year of the pub (year of publication), IFA (Indirect immunofluorescent Assay), ELISA (Enzyme-Linked Immunosorbent Assay), SIn (Sample Index values), PP (Percent Positivity), S/P (Sample to Positive ratios), AV (Absorbance Values), IgG (Immunoglobulin G) 


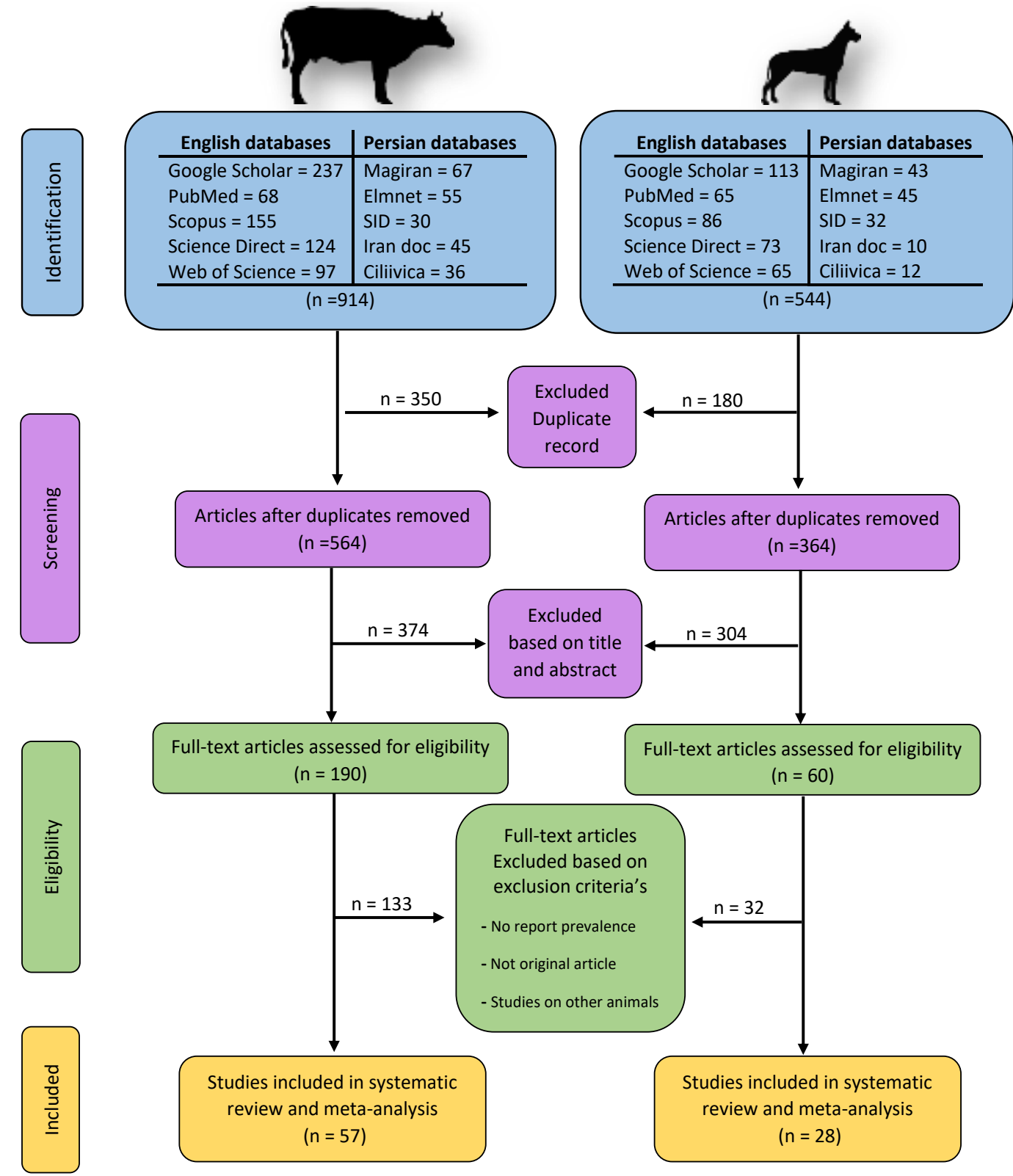

Fig. 1: Flowchart presenting the selection of articles analyzed in this systematic review and meta-analysis

\section{Statistical Analysis}

For this study, we supposed that the population under the study of included studies are random samples from a study population, therefore the random-effects model (DerSimonian and Laird, 2015; Cleophas et al., 2017), was also used to determine the overall prevalence of cattle and dog neosporosis. Proportions of individual studies, overall prevalence and the heterogeneity among studies were presented by forest plots. The heterogeneity was expected in advance and statistical methods, Cochran's Q test and $\mathrm{I}^{2}$ index were used to assess the heterogeneity among the studies (Ruppar, 2020). The effects of probable factors in heterogeneity were evaluated by the meta-regression method. The Egger's regression and Begg's test and funnel plotting were used to assess publication bias.

The meta-analysis was performed with the trial version of StatDirect statistical software available from the public domain i.e., http://statdirects.com. To visualize the prevalence of cattle neosporosis in the different provinces of Iran. Furthermore, the Arc GIS 10.3 software was applied to map the distribution of neosporosis in different provinces of Iran. 


\section{Results}

In total, 1458 articles (914 for cattle and 544 for dogs) were found by searching the entire databases from 2004 to 2020; by systematic review and meta-analysis by considering the inclusion criteria. Of this, 85 studies (57 for cattle and 28 for dogs) has met the evaluation criteria of this study (Table 1).
A total number of 17,837 cattle and 5,565 dogs were examined for neosporosis in different geographical locations in Iran. In cattle and dogs, 4,118 and 1,066 cases, respectively, were detected positive using different detection tests as presented in Table 1. Data were extracted from twenty provinces in eight districts of Iran the distribution of reports in cattle and dogs is shown in Table 2.

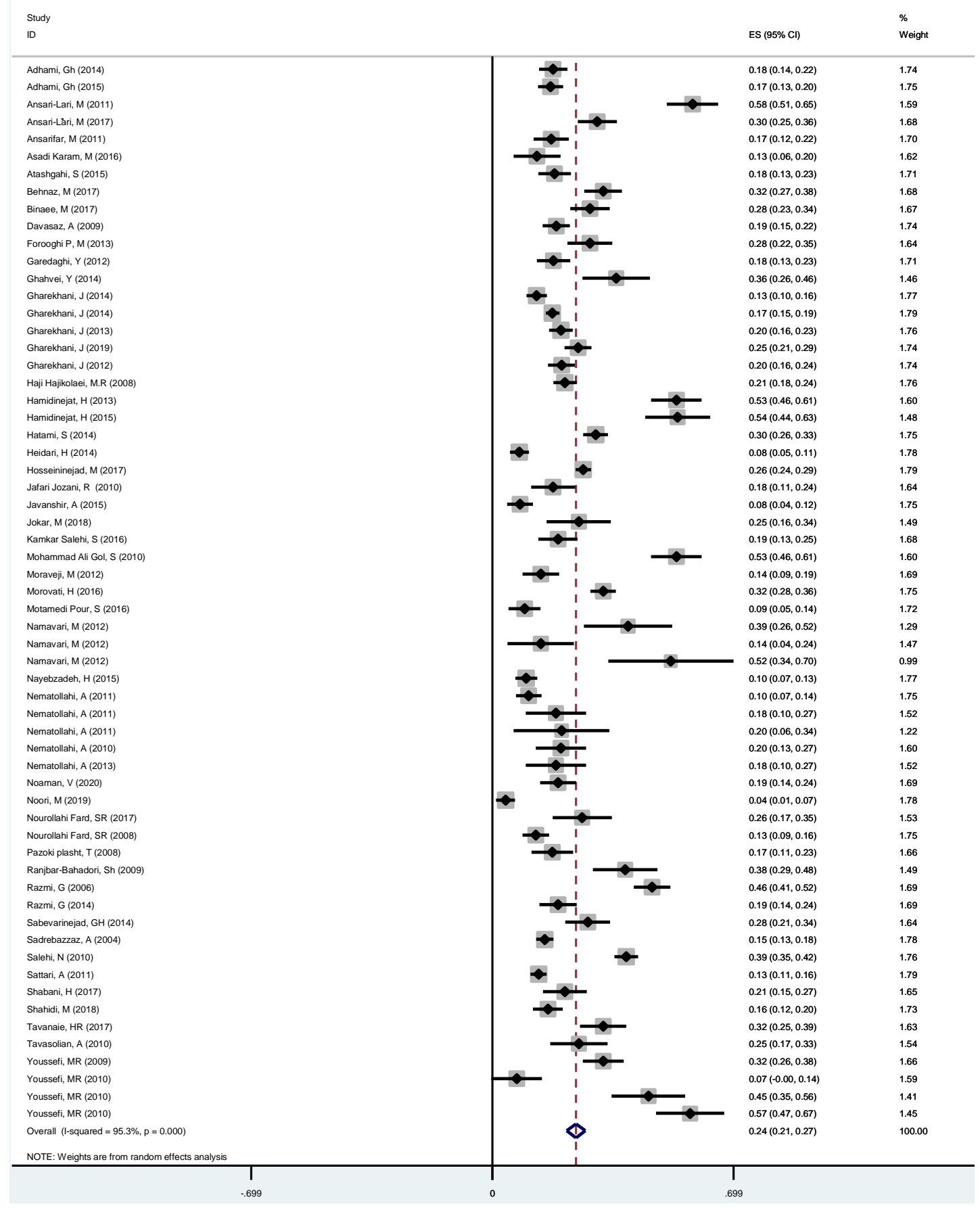

Fig. 2: Forest plot diagram showing portion meta-analysis plot of $N$. caninum infection prevalence in cattle in Iran (random-effects) 


\begin{tabular}{|c|c|c|c|}
\hline $\begin{array}{l}\text { Study } \\
\text { ID }\end{array}$ & & $\mathrm{ES}(95 \% \mathrm{Cl})$ & $\begin{array}{l}\% \\
\text { Weight }\end{array}$ \\
\hline Garedaghi, Y (2011) & $\longrightarrow$ & $0.31(0.22,0.40)$ & 3.31 \\
\hline Garedaghi, Y (2012) & $\longrightarrow$ & $0.31(0.22,0.40)$ & 3.31 \\
\hline Ghafarifar, F (2014) & $\bullet$ & $0.02(0.01,0.03)$ & 3.82 \\
\hline Ghanavati, S (2018) & $\rightarrow$ & $0.20(0.14,0.26)$ & 3.55 \\
\hline Gharekhani, J (2014) & - & $0.27(0.22,0.32)$ & 3.64 \\
\hline Gharekhani, J (2013) & & $0.27(0.22,0.32)$ & 3.64 \\
\hline Gharekhani, J (2014) & $\rightarrow$ & $0.10(0.07,0.13)$ & 3.76 \\
\hline Gharekhani, J (2014) & & $0.27(0.22,0.32)$ & 3.64 \\
\hline Gharekhani, J (2013) & 1 & $0.20(0.17,0.24)$ & 3.73 \\
\hline Gharekhani, J (2019) & $\rightarrow$ & $0.09(0.05,0.13)$ & 3.72 \\
\hline Gharekhani, J (2019) & $\rightarrow$ & $0.05(0.02,0.08)$ & 3.76 \\
\hline Haddadzadeh, H (2007) & 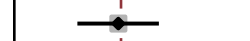 & $0.19(0.12,0.27)$ & 3.44 \\
\hline Hosseininejad, M (2010) & $\rightarrow$ & $0.10(0.06,0.14)$ & 3.72 \\
\hline Hosseininejad, M (2010) & $\rightarrow$ & $0.38(0.34,0.42)$ & 3.71 \\
\hline Hosseininejad, M (2019) & $\longrightarrow$ & $0.18(0.10,0.26)$ & 3.45 \\
\hline Hosseininejad, M (2017) & $\longrightarrow$ & $0.18(0.11,0.25)$ & 3.50 \\
\hline Hosseininejad, M (2010) & 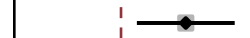 & $0.32(0.23,0.41)$ & 3.30 \\
\hline Javanshir, A (2015) & 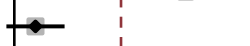 & $0.04(-0.01,0.09)$ & 3.63 \\
\hline Keyhani, p (2017) & & $0.22(0.14,0.30)$ & 3.40 \\
\hline Khanmohammadi, M (2011) & $\rightarrow$ & $0.11(0.08,0.14)$ & 3.76 \\
\hline Khordadmehr, M (2012) & & $0.55(0.45,0.64)$ & 3.28 \\
\hline Malmasi, A (2007) & $\infty$ & $0.33(0.24,0.42)$ & 3.29 \\
\hline Pouramini, A (2016) & 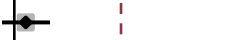 & $0.02(-0.02,0.07)$ & 3.69 \\
\hline Raesi, A (2009) & $\rightarrow \infty$ & $0.28(0.21,0.34)$ & 3.57 \\
\hline Razmi, G (2009) & $\rightarrow$ & $0.02(0.00,0.04)$ & 3.80 \\
\hline Sharifdini, M (2011) & $1 \rightarrow$ & $0.30(0.24,0.37)$ & 3.51 \\
\hline Yakhchali, M (2010) & $\stackrel{1}{1 \rightarrow-2}$ & $0.27(0.19,0.34)$ & 3.46 \\
\hline Yakhchali, M (2017) & $\rightarrow-1$ & $0.12(0.07,0.18)$ & 3.62 \\
\hline Overall $(I-$ squared $=96.7 \%, p=0.000)$ & & $0.20(0.15,0.24)$ & 100.00 \\
\hline NOTE: Weights are from random effects analysis & & & \\
\hline \begin{tabular}{r|r} 
& 1 \\
-.64
\end{tabular} & 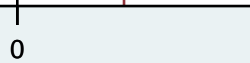 & & \\
\hline
\end{tabular}

Fig. 3: Forest plot diagram showing portion meta-analysis plot of N. caninum infection prevalence in dogs in Iran (random-effects)

Table 2: Frequency of studies based on province

\begin{tabular}{lll}
\hline Province & $\begin{array}{l}\text { Number of } \\
\text { reports Cattle }\end{array}$ & Dog \\
\hline Ardabil & 1 & 1 \\
Chaharmahal va Bakhtiari & 1 & 3 \\
East Azerbaijan & 8 & 3 \\
Fars & 7 & 1 \\
Golestan & 1 & - \\
Hamedan & 5 & 6 \\
Isfahan & 3 & 4 \\
Sistan and Baluchestan & 1 & - \\
Kerman & 3 & - \\
Kermanshah & 1 & - \\
Khuzestan & 5 & 3 \\
Kohgiluyeh and Boyer-Ahmad & 1 & - \\
Kurdistan & 3 & - \\
Lorestan & 2 & 1 \\
Mazandaran & 2 & - \\
Qazvin & 1 & - \\
Qom & 2 & 1 \\
Razavi Khorasan & 7 & 1 \\
Semnan & 4 & - \\
Tehran & 3 & 3 \\
West Azerbaijan & - & 3 \\
\hline
\end{tabular}

Three types of detection tests were employed to assess neosporosis infection in cattle and dogs as in the following: Enzyme-Linked Immunosorbent Assay (ELISA, 67 studies), Indirect Immunofluorescent assay (IFA, 15 studies) and polymerase chain reaction (PCR, 3 studies just in dog).

Overall, the pooled prevalence of neosporosis, using random-effects meta-analysis, among cattle and dogs was estimated at $24.2 \%$ (95\% CI, 21.5-26.9) and $19.9 \%$ (95\% CI, 15.3-24.4) respectively (Fig. 2 and 3). There was a high degree of heterogeneity in the prevalence estimates between different studies was observed in cattle, Q statistic $=1285.95(\mathrm{df}=60), \mathrm{P}<0.0001$ and $\mathrm{I}^{2}=$ $95.3 \%$ and in dog, $\mathrm{Q}$ statistic $=817.36(\mathrm{df}=26)$, $\mathrm{P}<0.0001$ and $\mathrm{I} 2=96.8 \%$.

Multivariate meta-regression analysis did not display any heterogeneity in dogs and publication year, province, detection method, testing cut-off levels and type of array in cattle studies (Table 3), but the district of studies in cattle might be the cause of heterogeneity $(p=0.029)$. Univariate meta-regression analyses indicated that Sample size of studies in cattle $(p=0 \cdot 013)$ and 
publication year of studies in dogs $(p=0 \cdot 013)$ might be the cause of heterogeneity, while we identified no meaningful differences in detection method, testing cutoff levels, type of array, districts and province (Table 3).

Table 3: Result of Multivariate and Univariate meta-regression model for detecting probable sources of heterogeneity

\begin{tabular}{|c|c|c|c|c|c|c|c|c|}
\hline \multirow{3}{*}{$\begin{array}{l}\text { Probable source } \\
\text { of heterogeneity }\end{array}$} & \multicolumn{4}{|l|}{ Cattle } & \multicolumn{4}{|l|}{ Dog } \\
\hline & \multicolumn{2}{|l|}{ Multivariate } & \multicolumn{2}{|l|}{ Univariate } & \multicolumn{2}{|l|}{ Multivariate } & \multicolumn{2}{|l|}{ Univariate } \\
\hline & Coefficient & P-value & Coefficient & $\mathrm{P}$-value & Coefficient & $\mathrm{P}$-value & Coefficient & p-value \\
\hline Year & -0.0092731 & 0.076 & -0.0060815 & 0.225 & -0.0105618 & 0.183 & -0.0136308 & 0.041 \\
\hline Sample size & -0.0000236 & 0.722 & 0.0004783 & 0.041 & -0.000152 & 0.426 & -0.000023 & 0.904 \\
\hline Districts & -0.0166418 & 0.029 & -0.0133732 & 0.065 & -0.0318206 & 0.185 & -0.0151036 & 0.329 \\
\hline Province & 0.0023875 & 0.539 & 0.0041939 & 0.233 & 0.0184053 & 0.088 & 0.0020018 & 0.767 \\
\hline Detection method & -0.1722615 & 0.128 & -0.0865771 & 0.358 & 0.0918528 & 0.480 & -0.0640048 & 0.072 \\
\hline Testing cut-off levels & $0.0177409)$ & 0.395 & 0.0136295 & 0.434 & -0.0248123 & 0.573 & -0.0250503 & 0.075 \\
\hline Type of array & - & - & -0.0000541 & 0.364 & -0.2381858 & 0.084 & -0.1310803 & 0.085 \\
\hline
\end{tabular}

Table 4: overall prevalence of neosporosis in different districts of Iran

\begin{tabular}{|c|c|c|c|c|}
\hline \multirow[b]{2}{*}{ Districts } & \multicolumn{2}{|l|}{ Cattle } & \multicolumn{2}{|l|}{ Dog } \\
\hline & Pooled prevalence & $5 \%$ Confidence interval] & Pooled prevalence & $5 \%$ Confidence interval] \\
\hline North & 32.8 & $25.1-40.5$ & 25.9 & $12.6-39.3$ \\
\hline Northwest & 16.5 & $13.5-19.5$ & 23.2 & $14.6-31.8$ \\
\hline Northeast & 22.8 & $16-29.6$ & 2.2 & $0-4.4$ \\
\hline West & 19.0 & $15.5-22.6$ & 19.4 & $12.2-26.5$ \\
\hline Center & 22.0 & $13.3-30.7$ & 11.0 & $1.9-20.1$ \\
\hline South & 35.0 & $22.5-47.4$ & - & - \\
\hline Southwest & 37.0 & $23.9-50.1$ & 30.6 & $10-51.2$ \\
\hline Southeast & 9.3 & $4.3-14.3$ & - & - \\
\hline
\end{tabular}

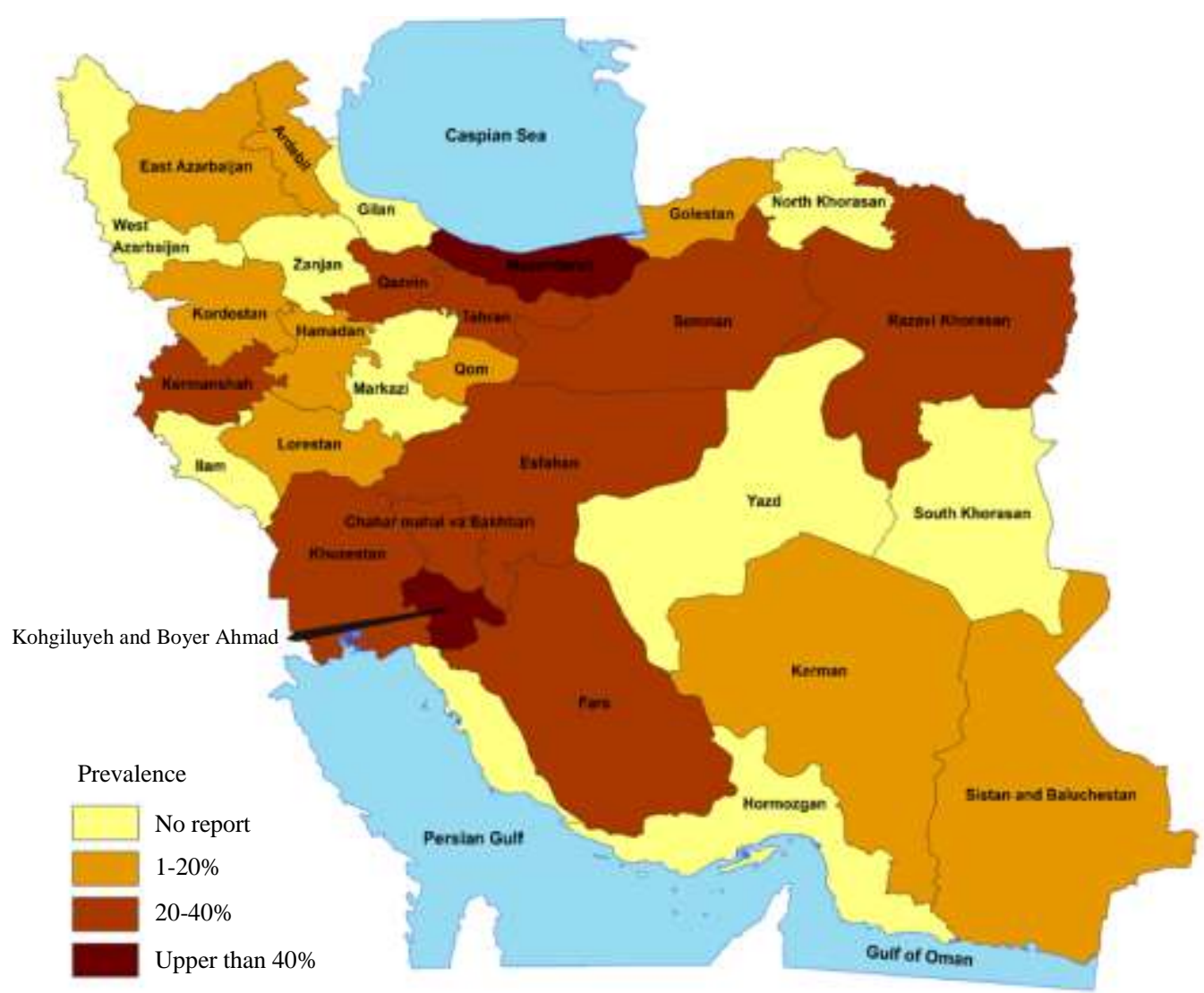

Fig. 4: Prevalence of neosporosis in cattle in different provinces of Iran 


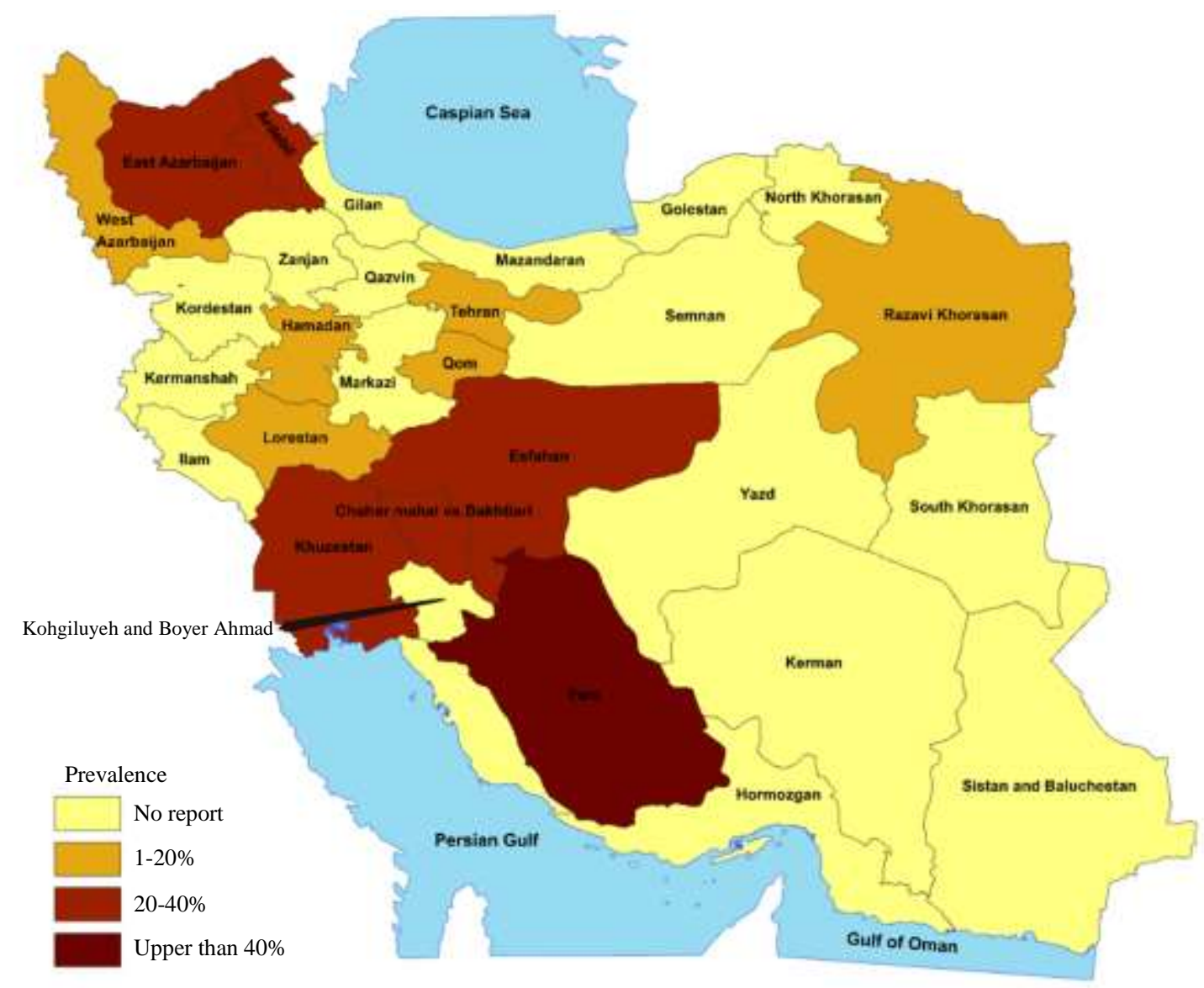

Fig. 5: Prevalence of neosporosis in dogs in different provinces of Iran
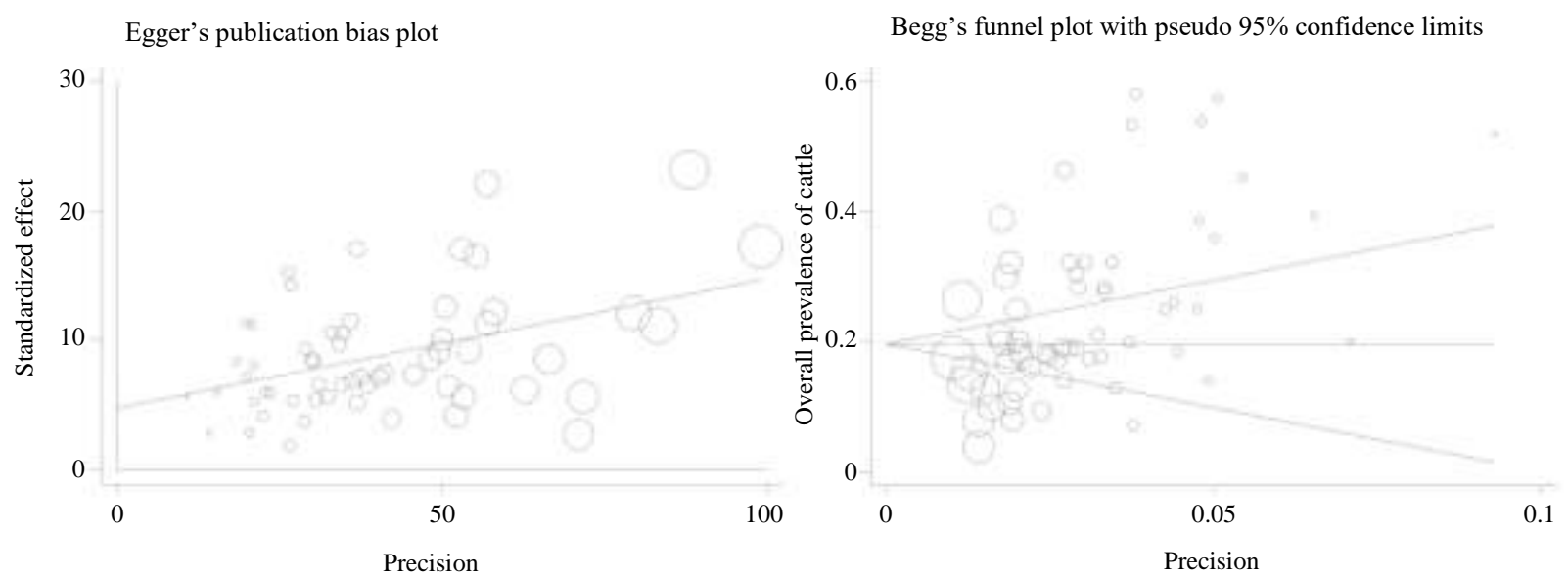

Fig. 6: Egger plot (a) and Begg's funnel plot with pseudo 95\% confidence limits (b) for detection of publication bias in cattle

The overall prevalence of cattle and dog neosporosis in eight geographical regions of Iran is presented in Table 4. Also, a schematic image of neosporosis in cattle and dogs distribution was made based on studies conducted in the provinces of Iran (Fig. 4 and 5). 

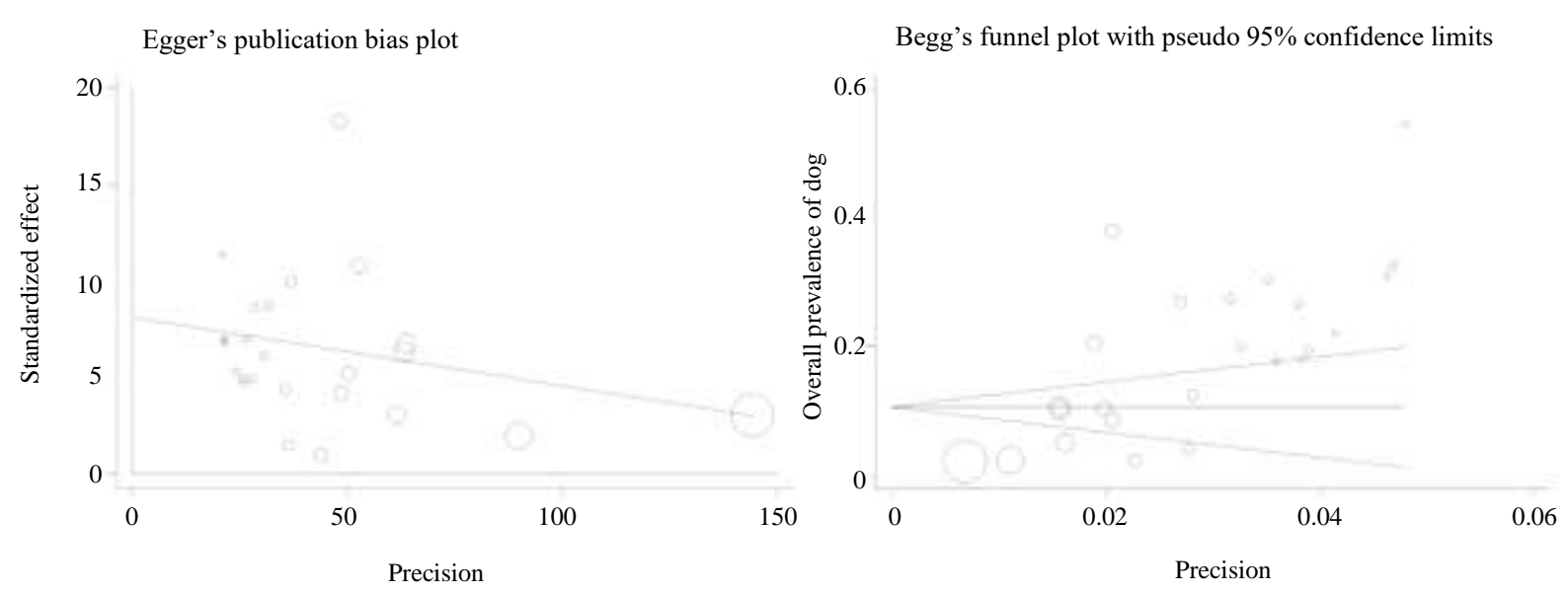

Fig. 7: Egger plot (a) and Begg's funnel plot with pseudo 95\% confidence limits (b) for detection of publication bias in dogs

\section{Publication Bias}

Egger and Begg's tests were applied to check the presence of publication bias. The Begg's test $(\mathrm{z}=$ $3.62, \mathrm{p}=0.000$ in cattle and $\mathrm{z}=2.69, \mathrm{p}=0.007$ in dogs) and the Egger test (bias $=4.75,95 \% \mathrm{CI}=2.26-7.23$ in cattle and bias $=8.11,95 \% \mathrm{CI}=5.46-10.76$ in dogs), indicating a significant publication bias of studies as shown in Fig. 6 and 7.

\section{Discussion}

The present study is the systematic review and metaanalysis that investigated both cattle and dog neosporosis, which is focused on Iran. This review was considered using 10 databases, 85 studies, 23,402 cattle and dogs and 2,862 positive cases. The present of this study showed that the overall prevalence of cattle neosporosis was $24.2 \%$ (95\% CI, 21.5-26.9). The worldwide prevalence of $N$. caninum in cattle was estimated to be $20 \%$ (95\% CI, 18-21), but our findings show an upper than to this range (Ribeiro et al., 2019). Despite, the mean prevalence of cattle neosporosis in the neighboring countries of Iran are as follows: In Turkey, two studies using the ELISA method in Central Anatolia, Kırşehir and Kars areas indicated that the prevalence were 13.96, 18.1 and 2\%, respectively (Akca et al., 2005; Y1ldiz et al., 2017) and, in some Iraqi provinces, the overall prevalence of neosporosis was $17.5 \%$ (Mallah et al., 2012). Which are lower than the pooled prevalence in Iran. However, In Pakistan, two studies using the ELISA method in Punjab and Sindh provinces disclosed that the prevalence was 43.8 and $43 \%$, respectively (Shabbir et al., 2011; Nazir et al., 2013). Which is higher than the pooled prevalence in Iran. If this high prevalence of bovine neosporosis is not controlled in Iran, it can lead to economic losses such as reproductive failure, expenses for professional help and diagnosis, lengthened intervals for rebreeding and culled cows' replacement, reduction of milk yield and reduced weight gain in infected animals (Trees et al., 1999; Ortega-Mora et al., 2006).

In the meta-analysis of subgroups, the highest prevalence of cattle neosporosis was estimated in Kohgiluyeh and Boyer-Ahmad province, in the southwest part of Iran as $51.7 \%$ and the lowest prevalence was found in Sistan and Baluchestan province, in the southeast of the country as 3.8\%. There is a variation among the prevalence in each part of the country, which might be as a result of several causes such as the age, gender and Breeds of investigated animal, presence of an intermediate host, sampling and study methods, different years and various seasonal periods, farms management, food storage, contact with carnivores, distinct geographical regions and humid and temperate climate effect on viability and sporulation of $N$. caninum oocysts (Dubey et al., 2007; Atkinson et al., 2000).

The existence of dogs on the farm is a risk factor related to the seroprevalence of neosporosis in cattle (Moore and Venturini, 2018; Ribeiro et al., 2019) and close contact with rodents and poultry had a significant association with cattle neosporosis (Barling et al., 2001; Gharekhani and Yakhchali, 2019). Several investigations indicate that the eating of feed or water contaminated with $N$. caninum oocysts shed by dogs and ingesting of the aborted materials with carnivores played an important role in increasing horizontal transmission and postnatal infection in cattle (Malmasi et al., 2007; Haddadzadeh et al., 2007; McAllister, 2016). Furthermore, this study showed that the pooled prevalence of $N$. caninum infections between dogs in Iran was $19.9 \%$ (95\% CI, 15.3-24.4). That compares to 
the global rate $(17.14 \%)$ Iran has a higher prevalence (Anvari et al., 2020). The mean prevalence of canine neosporosis in the neighboring countries of Iran is as follows: According to the worldwide meta-analysis study, the pooled prevalence in Turkey was $23.87 \%$ (Anvari et al., 2020) and in Pakistan, one study using the ELISA method disclosed that the seroprevalence was 23.5\% (Nazir et al., 2014). Both prevalences are higher than the pooled prevalence in Iran.

In the meta-analysis of subgroups, the highest prevalence of neosporosis among dogs was estimated in Fars province, in the south part of Iran as $54.6 \%$ and the lowest prevalence was found in Lorestan province, in the west of the country as $2.1 \%$. The reason for this wide variation is the existence of many risk factors associated with $N$. caninum infection, including Age, Gender, particular Breed, presence of an intermediate host, Type of living or feeding, coinfections and climate that could affect the transmission, sporulation and oocyst survival (Anvari et al., 2020; Collantes-Fernández et al., 2008; Reichel et al., 2007).

A study demonstrated that there is an association between climate and neosporosis frequency in Iran. $N$. caninum infection among cattle in cold climate regions is less than those in warm, dry and mild climate areas (Youssefi et al., 2010). In the current study, the prevalence was considerably high in Southwest of Iran, $37 \%$ in cattle and $30.6 \%$ in dogs, because it is located in warm, dry and mild climate areas compared to other parts of Iran. Furthermore, the prevalence in East Azerbaijan (15.4\% in dogs), West Azerbaijan (16.8\% in cattle) and Ardabil (7\% in cattle) provinces, which are located in the northwest of Iran, was relatively low. This low rate may be due to the reality that all cold mentioned and mountainous regions are not in favor of oocyst sporulation and survival (Dubey et al., 2017).

Integrated control strategies and measures should be considered to prevent and control neosporosis in canines, which will have important implications for controlling neosporosis in intermediate hosts such as sheep, goats and cattle. The diet source of the animal plays a momentous role in the horizontal transmission and as well as for the completion of the $N$. caninum life cycle (Dubey et al., 2007). However, the existence of canine working may inhibit visits from other canids on the farm, decreasing the risk of neosporosis in cattle (Barling et al., 2001). The removal of seropositive animals with a history of abortion to decrease the infection rate and economic burden consequently was suggested (Ansari-Lari et al., 2017).

This study has its limitations; such an analysis is limited due to the heterogeneity among studies' results. Even though there are widespread research studies and a large number of these may have been done on this subject, but they have not been publicly available. The current meta-analysis excluded these theses. This can explain as one of the reasons for the publication bias in the present study.

\section{Conclusion}

In conclusion, the pooled prevalence of cattle and dogs neosporosis in Iran is relatively high at 24.2 and $19.9 \%$, respectively. This value differs among geographical regions as it is the maximum in the Southwest for both and the minimum in Northeast for cattle and Southeast for dogs of Iran. These results are desirable for managing the control programs of this infection.

Furthermore, there is a clear gap in the prior studies, firstly there is no enough attention paid to the risk factors containing: The presence of dogs, age and breed of studied cattle and type of production system and the important role of them in the epidemiology of the disease. Secondly, there is no enough paid to the reproductive performance of seropositive cattle and subsequently their economic losses. Hence, all the above-mentioned parameters are required to consider to overcome these shortcomings in the future. An emphasis should be made prevention of the infection at the farm level by using procedures to test bulk milk, cattle and dogs.

\section{Acknowledgment}

The authors hereby would like to express their gratitude and appreciation to Dr. Mehran Farhoodi for collaboration and providing advice on the implementation of this meta-analysis in different stages and sections.

\section{Authors' Contributions}

Mohammad Jokar: Organized the study, proposal of study writing, data gathering, manuscript preparation, literature search and final revision of the study.

Saied Bokaie: Proposal of study writing, analysis and interpretation of data, manuscript editing, final revision of the study content, final approval of the revision the manuscript.

Vahid Rahmanian: Design of study, analysis and interpretation of data literature search and final revision of the study content, final approval of the version the manuscript.

Razieh Zahedi: Design of study, analysis and interpretation of data literature search and final revision of the study content, final approval of the version the manuscript.

Nader Sharifi and Hekmatollah Khoubfekr: Data gathering, manuscript editing, literature search and final revision of the study content, final approval of the version the manuscript. 


\section{Ethics in Systematic Reviews}

The authors of this study followed the ethical principles of Systematic Reviews, including guidance on authorship, avoiding redundant (duplicate) publication, avoiding plagiarism, transparency, ensuring accuracy that potential complications.

\section{Conflict of Interest}

The authors declared that there are no conflicts of interest.

\section{References}

Adhami, G. H., Hoghooghi, R. N., \& Dalimi, A. A. (2014). The SERO epidemiological investigation into neospora caninum in cattle in sanandaj, kordestan province.

Adhami, G., Dalimi, A., Ranjbar-Bahadori, S., \& Morovati, H. (2015). Evaluation of Neospora caninum infection in industrial and traditional dairy farms of Sanandaj province by IFAT. J Large Anim Clin Res, 8(1), 53-62.

Ahmad, N., Jozani, J., \& Neda, Z. (2011). Adaptation of Dot-Elisa for serodiagnosis of Neospora caninum infestation in aborted cows. Global Veterinaria, $7(2), 149-152$.

Akca, A., Gokce, H. I., Guy, C. S., McGarry, J. W., \& Williams, D. J. (2005). Prevalence of antibodies to Neospora caninum in local and imported cattle breeds in the Kars province of Turkey. Research in veterinary science, 78(2), 123-126.

Ansarifar, M. (2011). Investigation of the neospora caninum prevalence in livestock farms in Alborz province by ELISA, Master's Thesis, School of Veterinary Medicine, Islamic Azad University of Karaj Branch, Karaj, Iran. https://elmnet.ir

Ansari-Lari, M., Ahmadnia, S., Moraveji, M., Bahrami, S., \& Hosseini, A. (2011). Seroepidemiological study of Neospora caninum in dairy cattle, Iran. Online J Vet Res, 15, 155-161.

Ansari-Lari, M., Rowshan-Ghasrodashti, A., Jesmani, H., Masoudian, M., \& Badkoobeh, M. (2017). Association of Neospora caninum with reproductive performance in dairy cows: A prospective study from Iran. In Veterinary Research Forum (Vol. 8, No. 2, p. 109). Faculty of Veterinary Medicine, Urmia University, Urmia, Iran.

Anvari, D., Saberi, R., Sharif, M., Sarvi, S., Hosseini, S. A., Moosazadeh, M., ... \& Daryani, A. (2020). Seroprevalence of Neospora caninum infection in dog population worldwide: A systematic review and meta-analysis. Acta Parasitologica, 1-18.

Asadi Karam, M. (2016). Serological Survey of Neospora Caninum Infection in Cattle in Shahr-eBabak City, Master's Thesis, School of Veterinary Medicine, Shahrekord University, Shahrekord, Iran. https://irandoc.ac.ir
Atashgahi, S. (2015). Seroprevalence of Neospora caninum infection of dairy cows in neyshabor using ELISA method, Master's Thesis, School of Veterinary Medicine, Shahrekord University, Shahrekord, Iran. https://irandoc.ac.ir

Atkinson, R. A., Cook, R. W., Reddacliff, L. A., Rothwell, J., Broady, K. W., Harper, P. A. W., \& Ellis, J. T. (2000). Seroprevalence of Neospora caninum infection following an abortion outbreak in a dairy cattle herd. Australian Veterinary Journal, 78(4), 262-266.

Barling, K. S., McNeill, J. W., Paschal, J. C., Mccollum Iii, F. T., Craig, T. M., Adams, L. G., \& Thompson, J. A. (2001). Ranch-management factors associated with antibody seropositivity for Neospora caninum in consignments of beef calves in Texas, USA. Preventive Veterinary Medicine, 52(1), 53-61.

Behnaz, M. K. (2017). Development and evaluation of an in- house ELISA test for anti- Neospora caninum antibodies detection in in cattle, Master's Thesis, School of Veterinary Medicine, Shahid Chamran Ahvaz University, Ahvaz, Iran. https://irandoc.ac.ir

Binaee, M. (2017). Serological examination of Neospora caninum contamination in dairy cows of Semnan city, Master's Thesis, School of Veterinary Medicine, Semnan University, Semnan, Iran. https://irandoc.ac.ir

Chatziprodromidou, I. P., \& Apostolou, T. (2018). Diagnostic accuracy of enzyme-linked immunosorbent assay (ELISA) and immunoblot (IB) for the detection of antibodies against Neospora caninum in milk from dairy cows. Epidemiology \& Infection, 146(5), 577-583.

Cleophas, T. J., \& Zwinderman, A. H. (2017). Metaanalysis and Random Effect Analysis. In Modern Meta-Analysis (pp. 51-62). Springer, Cham.

Coelho, A. M., Cherubini, G., De Stefani, A., Negrin, A., Gutierrez-Quintana, R., Bersan, E., \& Guevar, J. (2019). Serological prevalence of toxoplasmosis and neosporosis in dogs diagnosed with suspected meningoencephalitis in the UK. Journal of Small Animal Practice, 60(1), 44-50.

Collantes-Fernández, E., Gómez-Bautista, M., Miró, G., Álvarez-García, G., Pereira-Bueno, J., Frisuelos, C., \& Ortega-Mora, L. M. (2008). Seroprevalence and risk factors associated with Neospora caninum infection in different dog populations in Spain. Veterinary Parasitology, 152(1-2), 148-151.

Curtis, B., Harris, A., Ullal, T., Schaffer, P. A., \& Munoz Gutierrez, J. (2020). Disseminated Neospora caninum infection in a dog with severe colitis. Journal of Veterinary Diagnostic Investigation, 32(6), 923-927.

Davasaz, A. (2009). Seroprevalence of Neospora caninum in dairy farms of Tabriz region. In: 1th National Congress of Veterinary Laboratory Sciences, pp. 211-212. https://civilica.com 
de Aquino Diniz, L. V., Minutti, A. F., Nino, B. D. S. L., Costa, L. R., Bosculo, M. R. M., de Almeida, B. F. M., ... \& de Barros, L. D. (2019). Vertical transmission of Neospora caninum in bovine fetuses from a slaughterhouse in Brazil. Tropical animal health and production, 51(6), 1751-1755.

de Oliveira, F. C. R., Gallo, S. S. M., Bôa-Morte, M. D. O., \& Ederli, N. B. (2019). Association of reproductive problems and dairy cow productivity in a farm with an outbreak of neosporosis abortion in Brazil. Am J Anim Vet Sci., 14: 7-12.

Decôme, M., Martin, E., Bau-Gaudreault, L., \& O'Toole, E. (2019). Systemic disseminated Neospora caninum infection with cutaneous lesions as the initial clinical presentation in a dog. The Canadian veterinary journal $=\mathrm{La}$ revue veterinaire canadienne, 60(11), 1177-1181.

Demir, P. A., Eşki, F., \& Ütük, A. E. (2020). Estimating the total economic costs of Neospora caninum infections in dairy cows in Turkey. Tropical Animal Health and Production, 52(6), 3251-3258.

DerSimonian, R., \& Laird, N. (2015). Meta-analysis in clinical trials revisited. Contemporary clinical trials, 45, 139-145.

Didiano, A., Monti, P., Taeymans, O., \& Cherubini, G. B. (2020). Canine central nervous system neosporosis: clinical, laboratory and diagnostic imaging findings in six dogs. Veterinary Record Case Reports, 8(1), e000905.

Dubey, J. P., Hemphill, A., Calero-Bernal, R., \& Schares, G. (2017). Neosporosis in animals. CRC Press.

Dubey, J. P., Schares, G., \& Ortega-Mora, L. M. (2007). Epidemiology and control of neosporosis and Neospora caninum. Clinical microbiology reviews, 20(2), 323-367.

Dwinata, I. M., Oka, I. B. M., Agustina, K. K., \& Damriyasa, I. M. (2018). Seroprevalence of Neospora caninum in local Bali dog. Veterinary world, 11(7), 926.

Fard, S. R. N., Khalili, M., \& Aminzadeh, A. (2008). Prevalence of antibodies to Neospora caninum in cattle in Kerman province, South East Iran. Veterinarski Arhiv, 78(3), 253.

Fereig, R. M., \& Nishikawa, Y. (2020). From Signaling Pathways to Distinct Immune Responses: Key Factors for Establishing or Combating Neospora caninum Infection in Different Susceptible Hosts. Pathogens, 9(5), 384.

Forooghi, P. M. (2013). Serologic prevalence of infection with Neospora caninum in dairy cattle in Shahrekord by ELISA, Master's Thesis, School of Veterinary Medicine, Shahrekord University, Shahrekord, Iran. https://irandoc.ac.ir
Ghafarifar, F., Sabevarinejad, G., Dalimi, A., \& Forouzandeh-Moghadam, M. (2014). Molecular detection of Neospora caninum from naturally infected dogs in Lorestan province, West of Iran. Archives of Razi Institute, 69(2), 185-190.

Ghahvei, Y. (2014). Serological survey do Neosporacaninum infection in cattle in Kermanshah, Master's Thesis. School of Veterinary Medicine, Shahid Bahonar University, Kerman, Iran. https://irandoc.ac.ir

Ghanavati, S. (2015). Investigation of serological and molecular prevalence of Neospora caninum parasite in Ahvaz city dogs, Master's Thesis, School of Veterinary Medicine, Shahid Chamran Ahvaz University, Ahvaz, Iran. https://irandoc.ac.ir

Gharekhani, J., \& Heidari, H. (2014). Serology based comprehensive study of Neospora infection in domestic animals in Hamedan province, Iran. Journal of Advanced Veterinary and Animal Research, 1(3), 119-124.

Gharekhani, J., \& Tavoosidana, G. (2013). Serological survey of Neospora caninum (Sarcocystidae) infection in beef cattle from western Iran. Scientia Parasitologica, 14(2), 95-98.

Gharekhani, J., \& Yakhchali, M. (2019). Neospora caninum infection in dairy farms with history of abortion in west of Iran. Veterinary and Animal Science, 8, 100071.

Gharekhani, J., Haddadzadeh, H., \& Bahonar, A. (2014a). Prevalence of immunoglobulin G (IgG) antibody to Neospora caninum in dairy cattle of Hamedan province, west of Iran. In Veterinary Research Forum: an International Quarterly Journal (Vol. 5, No. 2, p. 149). Faculty of Veterinary Medicine, Urmia University, Urmia, Iran.

Gharekhani, J., Tavoosidana, G., \& Akbarein, H. (2014b). Serological study of Neospora caninum infection in dogs and cattle from west of Iran. Comparative Clinical Pathology, 23(5), 1203-1207.

Gharekhani, J., Heidari, H., \& Akbarein, H. (2012). Seroepidemiology of Neospora caninum in Iranian native and crossbreed cattle: across sectional study. Journal of Veterinary Research, 67(4), 325-329.

Gharekhani, J., Yakhchali, M., Abbasi-Doulatshahi, E., \& Barati, E. (2019). Seroprevalence of Neospora caninum and Toxoplasma gondii infections in stray dogs of Hamadan suburb, west of Iran, 2018. Avicenna Journal of Clinical Microbiology and Infection, 6(2), 57-60.

González-Warleta, M., Castro-Hermida, J. A., Calvo, C., Pérez, V., Gutiérrez-Expósito, D., Regidor-Cerrillo, J., ... \& Mezo, M. (2018). Endogenous transplacental transmission of Neospora caninum during successive pregnancies across three generations of naturally infected sheep. Veterinary research, 49(1), 106. 
Hadad Zadeh, H. R., Shayan, P., Vojgani, M., \& Bolorchi, M. (2010). Serological study of Neospora caninum in pregnant dairy cattle in Tehran, Iran. Iranian Journal of Veterinary Medicine, 4(2).

Haddadzadeh, H. R., Sadrebazzaz, A., Malmasi, A., Ardakani, H. T., Nia, P. K., \& Sadreshirazi, N. (2007). Seroprevalence of Neospora caninum infection in dogs from rural and urban environments in Tehran, Iran. Parasitology research, 101(6), 1563-1565.

Haji Hajikolaei, M. R., Hamidinejat, H., Ghorbanpoor, M., \& Goraninejad, S. (2008). Serological study of Neospora caninum infection in cattle from Ahvaz area, Iran. Iranian Journal of Veterinary Medicine, 2(2), 63-66.

Hamidinejat, H., Hajikolaei, M. R. H., Ghorbanpoor, M., Namavari, M., \& Gol, S. M. A. (2013). Development and Standardization of Dot-ELISA for Detection of Neospora caninum Antibodies in Cattle and Comparison with Standard Indirect ELISA and Direct Agglutination Test (DAT). Iranian journal of parasitology, 8(4), 634.

Hamidinejat, H., Shapouri, M. R. S. A., Namavari, M. M., Shayan, P., \& Kefayat, M. (2015). Development of an indirect ELISA using different fragments of recombinant Ncgra7 for detection of Neospora caninum infection in cattle and water buffalo. Iranian Journal of Parasitology, 10(1), 69.

Hatami, S. (2014). Evaluation of production and reproduction data of a dairy farm after serological test for BLV, IBR, Johne's disease and Neosporosis, Master's Thesis, School of Veterinary Medicine, Ferdowsi University Mashhad, Mashhad, Iran. https://irandoc.ac.ir

Heidari, H., Mohammadzadeh, A., \& Gharekhani, J. (2014). Seroprevalence of Neospora caninum in slaughtered native cattle in Kurdistan province, Iran. In Veterinary research forum: an international quarterly journal (Vol. 5, No. 1, p. 69). Faculty of Veterinary Medicine, Urmia University, Urmia, Iran.

Hosseininejad, M., \& Hosseini, F. (2011). Seroprevalence of Neospora caninum and Toxoplasma gondii infection in dogs from west and central parts of Iran using two indirect ELISA tests and assessment of associate risk factors. Iranian Journal of Veterinary Research, 12(1), 46-51.

Hosseininejad, M., \& Hosseini, F. (2019). Seroprevalence of Neospora caninum and Toxoplasma gondii in dogs in Ahwaz, Iran.

Hosseininejad, M., Hosseini, F., Mosharraf, M., Shahbaz, S., Mahzounieh, M., \& Schares, G. (2010a). Development of an indirect ELISA test using an affinity purified surface antigen (P38) for serodiagnosis of canine Neospora caninum infection. Veterinary parasitology, 171(3-4), 337-342.
Hosseininejad, M., Hosseini, F., Mahzounieh, M. Nafchi, A. R., \& Mosharraf, M. (2010b). Seroprevalence of Neospora caninum infection in dogs in Chaharmahal-va-Bakhtiari Province, Iran. Comparative clinical pathology, 19(3), 269-270.

Hosseininejad, M., Mahzounieh, M., \& Esfandabadi, N. S. (2017). Neospora caninum suspects as one of the most important causes of abortion in large dairy farms in Isfahan, Iran. Iranian Journal of Parasitology, 12(3), 408.

Javanshir, A. (2015). Prevalence of Neospora caninum parasitic infection in dairy cattle and guard dogs in Qom Lebanon Complex using ELISA, Master's Thesis, School of Veterinary Medicine, Shahrekord University, Shahrekord, Iran. https://irandoc.ac.ir

Jin, X., Li, G., Zhang, X., Gong, P., Yu, Y., \& Li, J. (2017). Activation of a Neospora caninum EGFRlike kinase facilitates intracellular parasite proliferation. Frontiers in microbiology, 8, 1980.

Jokar, M., Amanatchi, A., Baghdadi, M., \& Nadia, T. (2018). Investigation of the simultaneous presence of Neospora caninum antigen and antibody in dairy cows in the suburbs of Qom province. In: 12th Congress of Iranian Veterinary Students, pp. 86-87. https://civilica.com

Kamkar-Salehi, S., \& Namavari, M. (2017). Study of using the triple Dot-ELISA for simultaneous diagnosis of Neospora caninum, IBR and BVDV. Vet Res Biol Prod, 30(4), 134-140.

Keyhani, P. (2017). Molecular study of Neospora caninum infection in dogs of Isfahan province.

Khan, A., Shaik, J. S., Sikorski, P., Dubey, J. P., \& Grigg, M. E. (2020). Neosporosis: An Overview of Its Molecular Epidemiology and Pathogenesis. Engineering, 6(1), 10-19.

Khanmohammadi, M., \& Fallah, E. (2011). Prevalence of Neospora caninum antibodies in shepherd dogs in Sarab district, East Azerbaijan province, Iran. African Journal of Microbiology Research, 5(28), 5062-5066.

Khordadmehr, M., Hosseini, S., Mohsenifar, E., Namavari, M., \& Khordadmehr, S. (2012). Seroprevalence of Neospora caninum in farm and household dogs determined by ELISA. Online J Vet Res, 16(4), 172-81.

Klein, C., Barua, S., Liccioli, S., \& Massolo, A. (2019). Neospora caninum DNA in coyote fecal samples collected in an urban environment. Journal of wildlife diseases, 55(1), 196-199.

Liberati, A., Altman, D. G., Tetzlaff, J., Mulrow, C., Gøtzsche, P. C., Ioannidis, J. P., ... \& Moher, D. (2009). The PRISMA statement for reporting systematic reviews and meta-analyses of studies that evaluate health care interventions: explanation and elaboration. Journal of clinical epidemiology, 62(10), e1-e34. 
Liu, Y., Reichel, M. P., \& Lo, W. C. (2020). Combined control evaluation for Neospora caninum infection in dairy: Economic point of view coupled with population dynamics. Veterinary Parasitology, 277, 108967.

Mallah, M. O., Dawood, K. A., \& Alrodhan, M. A. (2012). Seroepidemiological study for the prevalence of Neospora caninum in Dairy \& Beef cattle in some Iraqi provinces. Al-Qadisiyah Journal of Veterinary Medicine Sciences, 11(1), 103-110.

Malmasi, A., Hosseininejad, M., Haddadzadeh, H., Badii, A., \& Bahonar, A. (2007). Serologic study of anti-Neospora caninum antibodies in household dogs and dogs living in dairy and beef cattle farms in Tehran, Iran. Parasitology Research, 100(5), $1143-1145$

Marugan-Hernandez, V. (2017). Neospora caninum and bovine neosporosis: current vaccine research. Journal of comparative pathology, 157(2-3), 193-200.

McAllister, M. M. (2016). Diagnosis and control of bovine neosporosis. Veterinary Clinics: Food Animal Practice, 32(2), 443-463.

Mohammad Ali Gol, S. (2010). Development of DotELISA for diagnosis of Neospora caninum infection in cattle and Evaluation with Elisa Kit, Master's Thesis, School of Veterinary Medicine, Shahid Chamran Ahvaz University, Ahvaz, Iran. https://irandoc.ac.ir

Moore, D. P., \& Venturini, M. C. (2018). Neospora. In Parasitic Protozoa of Farm Animals and Pets (pp. 125-148). Springer, Cham.

Moraveji, M. (2012). Production of recombinant neospora caninum ncsag1 antigen for applying in setting of latex agglutination test (lat) and its comparison to the commercial elisa kit, Master's Thesis, School of Veterinary Medicine, Shiraz University, Shiraz, Iran. https://irandoc.ac.ir

Morovati, H., \& Noaman, V. (2016). Seroepidemiology of Neospora Caninum in Dairy Cattle Farms with a History of Abortion in Isfahan Province. Iran. J Vet Sci Anim Husb, 4(3), 304.

Motamedi Pour, S. (2016). Seroprevalence of Neospora caninum in lactating cattle of Sirjan peovince, Master's Thesis, School of Veterinary Medicine, Shahrekord University, Shahrekord, Iran. https://irandoc.ac.ir

Namavari, M., Hosseini, M. H., Mansourian, M., Shams, Z., Amrabadi, O., Tahamtan, Y., \& Moazeni-Jula, F. (2012). Testing for infective abortive agents in cattle in Iran. Online Journal of Veterinary Research, 16(3), 147-153.

Nayebzadeh, H., Nourollahi Fard, S. R., Khalili, M., Zakian, N., \& Taati, M. (2015). Seroprevalence of Neospora caninum infection in dairy cattle in west of Iran. Acta Vet Eurasia, 41(2), 162-166.
Nazir, M. M., Maqbool, A., Akhtar, M., Ayaz, M., Ahmad, A. N., Ashraf, K., ... \& Lindsay, D. S. (2014). Neospora caninum prevalence in dogs raised under different living conditions. Veterinary Parasitology, 204(3-4), 364-368.

Nazir, M. M., Maqbool, A., Khan, M. S., Sajjid, A., \& Lindsay, D. S. (2013). Effects of age and breed on the prevalence of Neospora caninum in commercial dairy cattle from Pakistan. The Journal of parasitology, 99(2), 368-370.

Nemat, E. A., \& Jafari, J. R. (2010). Study on pattern of Neospora caninum tachyzoite proteins by SDSPAGE and Western blotting in aborted cows.

Nematollahi, A., Jaafari, R., \& Moghaddam, G. (2011a). Seroprevalence of Neospora caninum infection in dairy cattle in Tabriz, Northwest Iran. Iranian Journal of Parasitology, 6(4), 95.

Nematollahi, A., Jafari, R., \& Moghaddam, G. (2011b). The study of infestation to Neospora caninum using the standardized domestic ELISA in dairy cows in suburb of Tabriz. Iran Vet J, 7(30), 57, [Persian]. https://magiran.com

Nematollahi, A., Moghaddam, G. H., Jaafari, R., Helan, J. A., \& Norouzi, M. (2013). Study on outbreak of Neospora caninum-associated abortion in dairy cows in Tabriz (Northwest Iran) by serological, molecular and histopathologic methods. Asian Pacific journal of tropical medicine, 6(12), 942-946.

Noaman, V., \& Nabinejad, A. R. (2020). Seroprevalence and risk factors assessment of the three main infectious agents associated with abortion in dairy cattle in Isfahan province, Iran. Tropical Animal Health and Production, 1-9.

Noori, M., Rasekh, M., Ganjali, M., \& FARD, S. R. N. (2019). Seroprevalence of Neospora caninum Infection and Associated Risk Factors in Cattle of Sistan Areas, Southeastern Iran in 2016. Iranian journal of parasitology, 14(2), 340.

Nourollahi-Fard, S. R., Khalili, M., Fazli, O., Sharifi, H., \& Radfar, M. H. (2017). Seroprevalence of Neospora caninum in cattle of Neishabour, northeast Iran. Slovenian Veterinary Research, 54(1), 5-9.

Ortega-Mora, L. M., Fernández-García, A., \& GómezBautista, M. (2006). Diagnosis of bovine neosporosis: recent advances and perspectives. Acta Parasitologica, 51(1), 1-14.

Pazoki Plasht, T., Rabie Far, O., Mohammad Sadegh, M., \& Gomashchi, H. (2008). Contamination of animals with a history of abortion with Brucella abortus, BVD, IBR and Neospora caninum. 15th Iranian Veterinary Congress, pp. 111-112. https://civilica.com

Pouramini, A., Jamshidi, S., Shayan, P., Ebrahimzadeh, E., Namavari, M., \& Shirian, S. (2017). Molecular and serological detection of Neospora caninum in multiple tissues and CSF in asymptomatic infected stray dogs. Iranian Journal of Veterinary Medicine, 11(2), 105-112. 
Raeisi, A. (2009). Seroprevalence of Neospora caninum infection in dogs of Chaharmahal and Bakhtiari province using indirect antibody test. http://ganjold.irandoc.ac.ir/articles/511596

Ranjbar, B. S., Motevaselian, A. H., Bokaie, S., \& Yousefi, M. (2010). Serological study of Neospora caninum in aborted dairy cattle in Garmsar.

Razmi, G. (2009). Fecal and molecular survey of Neospora caninum in farm and household dogs in Mashhad area, Khorasan province, Iran. The Korean journal of parasitology, 47(4), 417.

Razmi, G. R., Mohammadi, G. R., Garrosi, T., Farzaneh, N., Fallah, A. H., \& Maleki, M. O. H. S. E. N. (2006). Seroepidemiology of Neospora caninum infection in dairy cattle herds in Mashhad area, Iran. Veterinary Parasitology, 135(2), 187-189.

Razmi, G., Zarae, H., Norbakhsh, M. F., \& Naseri, Z. (2014). Estimating the rate of transplacental transmission of Neospora caninum to aborted fetuses in seropositive dams in Mashhad area, Iran. Iranian Journal of Veterinary Medicine, 7(4), 253-256.

Reichel, M. P., Ellis, J. T., \& Dubey, J. P. (2007). Neosporosis and hammondiosis in dogs. Journal of Small Animal Practice, 48(6), 308-312.

Reichel, M. P., Wahl, L. C., \& Ellis, J. T. (2020). Research into Neospora caninum - what have we learnt in the last thirty years?. Pathogens, 9(6), 505.

Ribeiro, C. M., Soares, I. R., Mendes, R. G., de Santis Bastos, P. A., Katagiri, S., Zavilenski, R. B., ... \& Afreixo, V. (2019). Meta-analysis of the prevalence and risk factors associated with bovine neosporosis. Tropical animal health and production, 1-18.

Rocchigiani, G., Poli, A., Nardoni, S., Papini, R., \& Mancianti, F. (2017). Neospora caninum in wild waterfowl: occurrence of parasite DNA and low antibody titers. Journal of Parasitology, 103(1), $142-145$.

Ruppar, T. (2020). Meta-analysis: How to quantify and explain heterogeneity?. European Journal of Cardiovascular Nursing, 19(7), 646-652.

Saber, E., Jafari, R., \& Ahmad, N. (2010). Comparison results of a domestic indirect ELISA for detection of antibodies Toxoplasma Gondeii to the results of a commercial ELISA for detection of antibodies Neospora Caninum, Iranian Journal of Veterinary Clinical Sciences, 4(1), 33. magiran.com/p1081512

Sabevarinejad, G. H. A., Dalimi, A., Ghafarifar, F., \& Forouzandeh-Moghadam, M. (2013). Serological survey of Neospora caninum infection in Holstein dairy cattle from Khoramabad region. Vet Res Biol Prod, 26(4), 48-54.

Sadrebazzaz, A., Haddadzadeh, H., Esmailnia, K., Habibi, G., Vojgani, M., \& Hashemifesharaki, R. (2004). Serological prevalence of Neospora caninum in healthy and aborted dairy cattle in Mashhad, Iran. Veterinary Parasitology, 124(3-4), 201-204.
Sattari, A., Moshiri, F., \& Musavi, S. (2011). The seroprevalence of Neospora caninum antibodies in dairy cattle herds in Golestan province, Iran. J Vet Microbiol, 7(1), 60-64.

Shabani, H., Rahimi, F., Fatahi, S., \& Angoti, M. (2017). Seroepidemiology investigation of cattle neosporosis in Qazvin city. 11th Iranian Congress of Veterinary Students, pp. 90-91. https://civilica.com

Shabbir, M. Z., Nazir, M. M., Maqbool, A., Lateef, M., Shabbir, M. A. B., Ahmad, A., ... \& Ijaz, M. (2011). Seroprevalence of Neospora caninum and Brucella abortus in dairy cattle herds with high abortion rates. Journal of Parasitology, 97(4), 740-742.

Shahidi, M., (2018). A study of neosporian abortion and congenital transmission in dairy farms of Torbat-E Heydariyeh area, Master's Thesis, School of Veterinary Medicine, Ferdowsi University Mashhad, Mashhad, Iran. https://irandoc.ac.ir

Sharifdini, M., Mohebali, M. E. H. D. I., Keshavarz, H., Hosseininejad, M., Hajjaran, H., Akhoundi, B., ... \& Charehdar, S. (2011). Neospora caninum and Leishmania infantum co-infection in domestic dogs (Canis familiaris) in Meshkin-Shahr district, Northwestern Iran. Iranian journal of arthropodborne diseases, 5(2), 60.

Silva, R. C., \& Machado, G. P. (2016). Canine neosporosis: perspectives on pathogenesis and management. Veterinary Medicine: Research and Reports, 7, 59.

Tavanaee, H. R., \& Namavari, M. (2017). Evaluation of attenuated variety of Neospora caninum for diagnosis of infection in cattle by agglutination test. Veterinary Researches \& Biological Products, 30(2), 153-157.

Tavasolian, A. H., Ranjbar-Bahadori, S., \& Youssefi, M. R. (2010). Seroepidemiology investigation of cattle neosporosis in garmsar city. 16th Iranian Veterinary Congress, pp. 78-79, (retrieved from https://civilica.com).

Trees, A. J., Davison, H. C., Innes, E. A., \& Wastling, J. M. (1999). Towards evaluating the economic impact of bovine neosporosis. International journal for parasitology, 29(8), 1195-1200.

Yagoob, G. (2012a). Seroepidemiology of Neospora caninum in cattle in East-Azerbaijan province, North West Iran. Journal of Animal and Veterinary Advances, 11(5), 645-648.

Yagoob, G. (2012b). Seroprevalence of Neospora caninum in Stray Dogs of Tabriz, Iran. Journal of Animal and Veterinary Advances, 11(6), 723-726.

Yakhchali, M., Bahrami, M., Asri-Rezaei, S., \& Bokaie, S. (2017). The enzymes and electrolytes profiles in sera of Iranian stray dogs naturally infected with Neospora caninum. Annals Ann Parasitol, 63(1), 63-68. 
Yakhchali, M., Javadi, S., \& Morshedi, A. (2010). Prevalence of antibodies to Neospora caninum in stray dogs of Urmia, Iran. Parasitology research, 106(6), 1455-1458.

Yıldız, K., Gökpınar, S., Sürsal, N., \& Değirmenci, R. (2017). Seroprevalence of Neospora caninum in Dairy Cattle Raised in Çiçekdaği District of Kırşehir Province. Turkiye parazitolojii dergisi, 41(3), 135-138.
Yousefi, M. R., ARAB, K. F., \& TABAR, M. H. A. (2009). Seroprevalence of Neospora caninum infection in rural and industrial cattle in northern Iran.

Youssefi, M. R., Ebrahimpour, S., \& Esfandiari, B. (2010). Survey of Neospora caninum antibody in aborting cattle from three climate regions of Iran. World Applied Science Journal, 10, 1448-1451. 